\title{
The effect of play therapy as a therapeutic communication on social interactions of children with special needs
}

\author{
Zikri Fachrul Nurhadi ${ }^{1}$, Rosanti Utami Dewi ${ }^{2}$, Syaidah Nurhalimah ${ }^{3}$ \\ ${ }^{1,2,3}$ Universitas Garut, Garut, Indonesia
}

\begin{abstract}
Therapeutic communication is one of the communications applied to Children with Special Needs (CSN), designed for therapy. This research is triggered by the number of Children with Special Needs who have not been accommodated to receive a complete education; this means Children with Special Needs have not been able to get an education because of various problems such as school places, parents inability, and the unwillingness of parents to let their children study which is influenced by social difficulties. Children with Special Needs typically feel scared, reluctant, hesitant, or unable to express themselves; these children are often excluded because they cannot communicate and socialize well, so that the impact is not good for the psychic, mental, social, and sensory of the children. This study aims to analyze the effect of empathy and warmth on associative and dissociative social processes. The research uses a study type with a quantitative approach with 50 people as samples. Data collection is carried out through primary data collection by using a questionnaire spread to several respondents and field observation to see the therapy used. The results showed that the empathy correlation coefficient value of the associative social process was 0.443 (strong enough), and the dissociative social process was 0.554 (strong enough). Meanwhile, the value of the warmth coefficient correlation to the associative social process was 0.850 (strong), and the dissociative social process was 0.880 (strong). Thus, the effect of play therapy as a therapeutic communication on social interaction is 0.428 (strong enough), while the achievement coefficient of determination is 0.283 . The independent variables have an influence and contribute with a rate of $28.3 \%$ to the independent variable.
\end{abstract}

Keywords: Children with special needs; parents; play therapy; social interaction; therapeutic

\section{ABSTRAK}

\section{Pengaruh terapi bermain sebagai komunikasi terapeutik terhadap interaksi sosial anak berkebutuhan khusus}

Komunikasi terapeutik menjadi salah satu komunikasi yang diterapkan pada Anak Berkebutuhan Khusus (ABK), yang dirancang untuk tujuan terapi. Penelitian ini dilatarbelakangi oleh banyaknya Anak Berkebutuhan Khusus yang masih belum dapat mengenyam pendidikan secara menyeluruh, artinya Anak Berkebutuhan Khusus belum dapat mengenyam pendidikan karena berbagai masalah seperti keterbatasan tempat sekolah, keterbatasan orang tua, serta ketidaksediaan orang tua untuk menyekolahkan anaknya yang dipengaruhi oleh sulitnya interaksi sosial. Permasalahan Anak Berkebutuhan Khusus merasa takut, enggan, ragu, atau tidak mampu mengekspresikan dirinya, sering dikucilkan karena tidak dapat berkomunikasi dan bersosialisasi dengan baik, sehingga berdampak tidak baik bagi psikis anak, mental, sosial dan sensorik. Penelitian ini bertujuan untuk menganalisis pengaruh empati dan kehangatan terhadap proses sosial asosiatif dan disosiatif. Metode penelitian ini menggunakan jenis studi dengan pendekatan kuantitatif dengan jumlah sampel penelitian sebanyak 50 orang. Pengumpulan data yang dilakukan yaitu pengumpulan data primer dengan menggunakan angket yang diberikan kepada sejumlah responden dan observasi lapangan untuk melihat terapi yang digunakan. Hasil penelitian menunjukkan bahwa nilai koefisien korelasi empati terhadap proses sosial asosiatif sebesar 0,443 (cukup kuat) dan terhadap proses sosial disosiatif yaitu 0,554 (cukup kuat). Sementara itu, nilai koefisien kolerasi kehangatan terhadap proses sosial asosiatif sebesar 0,850 (kuat) dan terhadap proses sosial disosiatif 0,880 (kuat). Pengaruh terapi bermain sebagai komunikasi terapeutik terhadap interaksi sosial sebesar 0,428 (cukup kuat), sedangkan ketercapaian angka koefisien determinasi diperoleh 0,283 , sehingga variabel bebas memiliki pengaruh dan memberikan kontribusi dengan angka 28,3\% terhadap variabel independen.

Kata-Kata kunci: Anak berkebutuhan khusus; interaksi sosial; orang tua; terapeutik; terapi bermain

Korespondensi: Dr. Zikri Fachrul Nurhadi, M.Si. Universitas Garut. Address Jln. Raya Samarang No. 52A Garut, Post Code 44151. West Java.Email: zikri_fn@uniga.ac.id. 


\section{INTRODUCTION}

Therapeutic communication in Indonesia is one of the important communications. This is related to the need for every human being to communicate to solve the problem facing, such as Children with Special Needs (CSN) to get access to social interaction. Social communication for Children with Special Needs (CSN) can be built through play therapy activities using game methods and tools to help stimulate the brain function of Children with Special Needs (CSN). The communication process is delivering ideas or feelings by the communicator to the interlocutor (communicant) (Ray, Rhine \& Jones, 2001).

There are various ways of human conducting communication: intrapersonal communication, interpersonal communication, intergroup communication, and mass communication. In implementing therapeutic communication executed by educators of Children with Special Needs (CSN), the teacher applies an interpersonal communication approach. The application or implementation of these interpersonal communication activities is different for each individual. Not all humans are born in a perfect state; some of them are physically/mentally retarded or have special needs. Therefore, there should be the special treatment of communication to enable their communication ability. This communication way that will affect the ability of an individual's social interaction (Windyaningrum, 2014). The term children with special needs refer to children who have differences from normal children such as physical, psychological condition, communication relation, quotient, intelligence, interest, feeling, or a combination of these characteristics (Iswari, 2007). Children with special needs can be interpreted as children who must be assisted, and special assistance is needed in the learning process or when building a relationship in communication (Wardani, 2014). Besides special needs, several other terms are used, such as children with disabilities, retarded children, handicapped children, and backward children. However, the latest terms used are children with special needs (a translation of English language for a child with special needs) and modifiable stands for difference ability) which have been internationally used (Salter, 2016).
Based on Government Regulation of the Republic of Indonesia Number 72 of 1991 concerning Special Needs Education, children with special needs are deaf, physically disabled, mentally retarded, visually impaired, and learning difficulties. Children included in the classification above are advised to attend formal education in Special Schools. Therapeutic communication is frequently used as a therapeutic approach for clients to overcome the problems faced through communication (Komariah, 2013). There are approaches in therapeutic communication, i.e., sincerity, warmth, and empathy (Arwani, 2012).

The importance of therapeutic communication should be understood by many parties, especially the parents or families of CSN as the closest ones. With the fast development of technology, parents or families of CSN can now search for information or do an online consultation. As stated on the website, hellosehat.com is a health consultation platform with many skillful workers and doctors, for example, dr. Tania Savitri as a pediatrician. dr. Tania Savitri says that children with special needs are often excluded because they cannot communicate and socialize well. This has a bad impact on the child's physic. As a result, the child does not want to interact. That's why one of the therapies used to change children's behavior with special needs is playing therapy. Playing is one of the most memorable stages in children's development, including children with special needs. Hopefully, with this therapy, CSN can change their behavior in a fun way (Reported by hellosehat.com: 2017). Based on this description, therapeutic communication will foster various ways of communication. The communication pattern is a representation of communication implementation, so with the model existence or communication description, the right way to communicate can be found, especially parents with children with special needs (Komariah, 2013).

The play therapy steps are conducted in several phases; the first phase by building trust through active listening and reading and unconditional acceptance, trying to provide assistance to the children and communicate patiently, identifying the characteristics of children with special needs who will be given therapy, determine games by the characteristics of children and prepare game tools that will 
be given, determine target behavior or goals to be achieved in therapy. It is better to teach slowly, structured, and continuously disaster mitigation lessons. Divide the target behavior into sessions. While the middle step is to start the therapy, providing information to children with special needs about the purpose of play therapy to be given, exploring and observing how children play, so in this way counselors can also help children to develop their creativity broadly, such as language skills, art, movement, drama and also develop children's emotional abilities in establishing relationships with their surroundings (Komariah, 2013).

The final step is for the therapist to end the therapy process that is treated by giving the child the opportunity to conclude what he gets from the game child plays. Therapy can be ended if the child has shown progress in various forms of positive behavior, especially the game's goal, and confirm what the child is right about the purpose of this game therapy. Play therapy is carried out by children using existing facilities or playing to avoid obstacles or disturbance (Komariah, 2013).

Based on the researcher's observation, the problem with this study is that most Children with Special Needs (CSN) feel afraid, reluctant, hesitant, or unable to express themselves well. This makes it difficult for children to carry out social interactions, so play therapy is needed. The existence of various toys that are familiar to children's eyes is expected to make it easier for children to interact. This is by the opinion of $\mathrm{dr}$. Tania Safitri that the games played effectively improve the relationship and social sensitivity within children. While doing play therapy, children tend to relax and open up, so they want to interact with other people. The social process is social interaction, while the particular form is social activities. Social interaction is a social fabric that has a flowing nature and a strong bond with a person or with other human groups. According to Gillin and Gillin, this interaction relationship is divided into two parts; they are associative and dissociative processes (Soekanto, 2013). The communication process is essentially a process of conveying thoughts or feelings by someone (the communicator) to another person (the communicant) (Effendy, 2013). The communication form carried out by humans are varied; they are intrapersonal communication, interpersonal communication, intergroup communication, and mass communication. In implementing therapeutic communication carried out by teachers with Children with Special Needs (CSN), the teacher applies an interpersonal communication approach.

Regarding therapeutic communication treatment to Children with Special Needs (ABK), based on data in 2016, there were around 189,000 children with special needs in West Java. Unfortunately, only $12 \%$ were able to get education access. This means that more than 160,000 children with special needs were not able to get an education because of various problems such as limited school places, parent's inability, and the unwillingness of parents to let their children go to school, which is influenced by social interactions difficulty (Republica.co.id Report, 2016). As one of the regions in West Java, the number of people with disabilities or special needs in Garut also showed a fairly high number. The description of the data was the same as the data released by Garut Central Bureau of Statistics, which revealed that there were 6068 people with disabilities in 2015, there were 6158 people with disabilities, in 2016 there were 6344 people with disabilities in 2017, and there were 6189 people with disabilities in 2018.

Based on the explanation above, the researchers set the theory of Social Learning as an analysis instrument in this research. As a theory, The Social Learning Theory is used to see the effectiveness of play therapy on children's social interaction with special needs. The Social learning theory is also known as observational learning. The pioneer of this theory is Albert Bandura. This theory explains that human behavior is not merely come naturally but is formed as a result of reaction arising from the interaction between environment and human knowledge view (Hergenhahn B.R, 2015). Inplay therapy activities conducted by teachers/ therapists for children with special needs are continuously carried out to help children understand the instructions given and train children's responses. The effect of play therapy as therapeutic communication on the social interaction of children with special needs is by previous research entitled The Effect of Play Therapy on Social Interaction of Autistic Children at SDLB Prof. Dr. Sri Soedewi Masjchun Sofwan, S.H Jambi 2014. The results 
of this previous study showed that in the first measurement (before play therapy), only $11.8 \%$ of respondents wanted to look into the eyes (meaning that the rest there was no interaction). Then the second measurement (after play therapy) showed that $64.7 \%$ would look into the eyes and turn when their names were called. In addition, children also want to be directed to do things as the therapist instructed. This is a significant ability considering that it was very difficult to give instructions to children. Further research reveals that play therapy has a good and significant effect based on treatment outcomes both for males and females. In addition, the effect is more dominant and has a strong share of play therapy when parents get involved in taking care of children (Ray, Rhine \& Jones, 2001).

The research also is relevant to the journal of communication research results for children with special needs, which explains that the form of support for CSN is not only focused on the children but also on creating a conducive environment. The positive emotions that the environment continues to give them great help their development towards improvement. Communication allows a person to express himself and create events, for example, by showing what he wants. Teachers, parents, and individuals around children with special needs should observe children with special needs and see what types of messages the child is trying to communicate and whether he uses gestures, sounds or words. When we know how each child communicates individually, three possibilities can be done, they are: (1) allowing the child to communicate more types of messages (2) teaching him both to respond to the other and also encouraging one to start a conversation (3) teaching higher communication skills, for example: Typically another person can understand more easily, and this can be used to communicate more complex ideas, such as expressing the desire through his armor rubbing his nose, then the teacher should imitate it (Nida, 2013). The researcher examines therapeutic communication at SLBC YKB Garut is very important; it is to improve the ability of Children with Special Needs (CSN) through various therapies. Normal people or those without special needs must also increase awareness of therapeutic communication to increase their communication quality.
The problem in this research is divided into several questions: (1) How does empathy affect associative and dissociative social processes, (2) How does warmth affect associative and dissociative social processes. Therefore this study aims to analyze the effect of empathy and warmth on associative and dissociative social processes.

\section{RESEARCH METHODS}

The type of study on this research uses a quantitative approach defined as research focusing on scientific thinking processes. Quantitative research tends to use variables, they are independent variable and dependent variable, and it is highly based on the opinion of experts (Sugiyono, 2015). The following is an explanation of the variables in this research. The data collection technique used in this study used a questionnaire technique then given to students who took part in play therapy as respondents and 50 of them as research samples. Meanwhile, the data analysis technique uses inferential data analysis technique. Inferential statistics include parametric statistics used for interval and ratio data and nonparametric statistics used for nominal and ordinal data. The inferential data analysis technique is carried out with inferential statistics; in this case, statistics are used to analyze data by making generally accepted conclusions (Sugiyono, 2015).

The independent variable is a variable that influences the presence of the dependent variable (Sugiyono, 2015). In this study, the independent variable is play therapy as therapeutic communication; therefore,, it has three derivatives based on therapeutic communication's main characteristics: sincerity, empathy, and warmth (Arwani, 2012). However, empathy and warmth will be discussed as an independent variable in this study. Empathy in this study describes feelings, understanding, and acceptance of the feelings experienced by children and the ability to feel. At the same time, warmth illustrates a warm, universal atmosphere and is free from any threat and inconvenience for children (Arwani, 2012).

The dependent variable is defined as a variable that is influenced by an independent variable (Sugiyono, 2015). The dependent variable (Y) in this study is the social 
interaction of Children with Special Needs (CSN), which is manifested in two forms, they are associative and dissociative (Soekanto, 2013). The associative process describes the importance of togetherness, good relation, and mutuality between one member and another where this process produces the same goal. Meanwhile, the dissociative process describes the existence of competition; resistance carried out in a community or group, and contravention (Soekanto, 2013).

\section{RESULTS AND DISCUSSION}

The result of this research describes the process of play therapy as therapeutic communication and the effect of play therapy on the social interaction of children with special needs at SLBC YKB Garut. Questionnaires were distributed to students' parents who took part in play therapy as respondents as many as 50 people. This is done because parents are parties who feel and see the development or progress of social interactions carried out by CSN directly. The parents of the SLBC YKB Garut students who were the respondents of this study had various economic and educational backgrounds. However, most of them realize the ability of children with special needs can be optimized with various kinds of therapy that can be treated at school. They support the program or school policy as long as the essence of the goodness of the activity they can understand. Furthermore, the respondent's criteria will be categorized into several categories; they are based on gender, education, occupation, and age of the respondents and based on the child'schild's age and the type of special needs of the child. Based on the research data, the majority of respondents in this study were 46 women or having a percentage of $92 \%$, and four other respondents were male with a percentage of $8 \%$ of the total. This is because of the division of roles between men and women in the household. The father's role is usually more dominant at work thanthan the mother, who accompanies and takes care of the children during school hours. In addition, a mother or woman in a family tends to be more sensitive and understand more deeply about their children's condition. Thus, they can see and feel the developments in their children.

Based on research data, most respondents are housewives who do not have a permanent job with a total of 37 people (74\%). While the rest of the respondents have jobs, four people work as traders, three as employees of a private company, three are Civil Servants (PNS), and one is an entrepreneur. Similar to the characteristics of respondents based on gender, which has been described previously, the large number of respondents who do not work is related to the division of duties or roles in the household. Respondents do not work and choose to become housewives to focus more on taking care of the house and children, especially children with special needs, because they need more attention. Meanwhile, characteristic data based on the respondent's age showed that from a total of 50 respondents in this study, 29 people were in the age range of 41-50 years, 14 people were in the age range of $31-40$ years, and 13 other people were in the age range of 51-50 years.

Based on the children's age characteristics showed that 11 of the 50 respondents aged 5-10 years, 33 people are 11-15 years old, five people are 16-20 years old, and one person is more than 20 years old. They are students of Kindergarten, Elementary, and junior high school at SLBC YKB Garut. Children with special needs who take education programs tend to be older than normal children in general. This is due to the postponement in the child's age when entering school or the length of time taken to study. Meanwhile, respondents based on the type of special needs showed that from 50 children as respondents of this study, 19 of them are diagnosed with mild mental retardation, 18 people with moderate mental retardation, and 13 others are categorized as autistic. This type of student's special needs is in accordance with the specialization of SLBC YKB Garut, which is intended for mentally retarded, autistic, and down 'syndrome children. Therefore, it is important to choose the right school specialization according to the special needs of the children because different diagnoses will have different ways of learning.

Children with mental retardation are those who have an IQ below the average. The grouping of mentally retarded is generally based on the level of intelligence, and this is measured using the Stanford Binet test and the Weschler Scale (WISC). Mild mental retardation (also called moron) is a child who has an IQ 68-52 
Table 1 The Recapitulation of Respondents Response Toward Teacher's Empathy (Therapeutic Communication) in Play Therapy

\begin{tabular}{lccc}
\hline \multicolumn{4}{c}{$\begin{array}{c}\text { Teacher's Empathy in } \\
\text { Play Therapy }\end{array}$} \\
\hline Alternative Answer & Option Category & Frequency & Percentage \\
\hline Strongly Agree & 5 & 175 & $50 \%$ \\
Agree & 4 & 152 & $43 \%$ \\
Doubt & 3 & 23 & $7 \%$ \\
Disagree & 2 & 0 & $0 \%$ \\
Strongly Disagree & 1 & 0 & $0 \%$ \\
& Total & 350 & $100 \%$ \\
\hline
\end{tabular}

Source: The researcher data calculation result, 2019

according to the Binet scale or IQ 69-55 on the Weschler scale. They can still learn to read, write and do simple arithmetic. Physically they look like normal children in general. Moderate intellectual disability (also called imbecile) are children who have IQ 51-36 on the Binet scale or IQ 54-40 on the Weschler scale. Children who have mental retardation are very difficult or even unable to learn academically (writing, reading, and counting) but can still be educated and trained to take care of themselves (Somantri, 2014). In contrast, autism is a developmental disorder caused by a disturbance in the central nervous system, which results in a disturbance in social interaction, communication, and child behavior.

The $\mathrm{X}$ Variable in this research is therapeutic communication which consists of two indicators. The two indicators are empathy and warmth. These two indicators are implemented by the therapist in the form of actions to children/students who are participants in play therapy. This empathy and warmth can be seen with the naked eyes and sensed through observations made. Dimensions of empathy consist of several indicators, and they are understanding, sensitivity, knowledge, direct action. At the same time, the indicator of warmth is eye contact, touch, hearing, and voice intonation. Based on the classification of variables, the researcher will explain the $\mathrm{X} 1$ variable about empathy. The first indicator of empathy understanding toward attitude is created from mutual understanding. In this case, the teacher's understanding in this play therapy activity is when the teacher understands that there are students who are physically weak or hyperactive, so they must be accompanied or guided directly by the teacher or other therapist assistants. The second indicator of empathy is the teacher sensitivity, who is capable of feeling and reading situations without the need for words from the child. Understanding the teacher in this play therapy activity is when the teacher realizes there are children who are in a bad mood, there are children who are angry because of the attitude or words of the teacher or his friends. The third indicator of empathy is knowledge, and it is to what extent a teacher knows information about his students or the extent to which a teacher knows his students. The teacher's knowledge of his students is that the teacher knows the type of illness or special needs of his students, knows information about the family or people closest to his students, and so on. The last indicator of empathy is direct action which is a variety of sincere, spontaneous actions that the teacher does for his students. Following are the results of the questionnaire recapitulation from several dimensions on variable $X$ (Empathy).

Table 1 can be explained that the tendency of choosing alternative answers is in the strongly agree option with 175 choices (50\%). Furthermore, the tendency of choosing to agree is 152 choices (43\%), and 23 other choices $(7 \%)$ are in doubtful options. This 350-frequency gain is recapitulated from 5 statement items regarding respondents' responses to the statement "teachers have sensitivity to what 
Table 2 The Recapitulation of Respondent's Response Toward Teacher's Warmth (Therapeutic Communication) in Play Therapy

\begin{tabular}{lccc}
\hline \multicolumn{4}{c}{$\begin{array}{c}\text { Teacher's Warmth in } \\
\text { Play Therapy }\end{array}$} \\
\hline Alternative Answers & Option Category & Frequency & Percentage \\
\hline Strongly Agree & 1 & 98 & $48 \%$ \\
Agree & 2 & 102 & $52 \%$ \\
Doubt & 3 & 0 & $0 \%$ \\
Disagree & 4 & 0 & $0 \%$ \\
Strongly Disagree & 5 & 0 & $0 \%$ \\
& Total & 200 & $100 \%$ \\
\hline
\end{tabular}

Source: The researcher data calculation result, 2019

students are experiencing and feeling (feeling changes in students' emotion and attitude)", respondents' responses to the statement "teachers feel what emotions are being sensed by students when carrying out play therapy", the respondent's response to the statement " teacher communicates orally, in writing, or with attitudes and other tools well, so that there is understanding between the teacher and the student", the respondent's response to the statement "the teacher knows important things about his students including age, background, child nature, illness suffered, respondents' response to the statement "teachers do not hesitate to help students with direct action if students have difficulty in communicating/ interacting/moving", respondents' response to the statement "teachers provide suggestion or solution to problem learning experienced by students. Therefore, the empathy conducted by the teacher as a therapist has been well executed.

After that, the researcher is going to explain the X2 variable of warmth. The first indicator of warmth is eye contact in the way the teacher looks at his student, the look in the eyes when the teacher faces facing with the student. The teacher's eye contact is played when the child is afraid of a new atmosphere or when the child asks for certainty. Eye contact can convey a person's feelings and moods; therefore, it is very important for therapists and patients to make eye contact during treatment activities. The second indicator of warmth is touch which is a representation of physical contact that the teacher makes with his students. The teacher guides children who are afraid of catching the ball. The third indicator of warmth is listening activity, which is the teacher's activity of listening to stories, complaints, desires, and opinions of students. This listening activity will increase the teacher's knowledge as a therapist and create a sense of comfort and trust from students. The fourth indicator of warmth is voice intonation used by the teacher when speaking or giving directions to students. Inplay therapy activities, teachers often have to repeat the instructions/rules of the game. Here are the results of questionnaire recapitulation from several dimensions on the $\mathrm{X}$ (warmth) variable.

From table 2, it can be seen that of the 200 total frequencies of choosing alternative answers, the tendency of respondents' choice of answers to agree is 102 frequencies. The other 98 frequencies are in the alternative answer strongly agree. The tendency of respondents' answers shows that the warmth performed by a teacher in play therapy activities is good. Warmth is a realization of teacher acceptance for all students' circumstances. The warmth of the teacher encourages children to express their ideas in words and attitudes freely. Warmth creates a sense of comfort and safety so that children can do everything as their wishes and needs. Warmth can be visualized through communication in the form of performance, voice intonation, soft-grip as a form of affection.

The Y Variable in this research is social interaction which is divided into associative process and dissociative process. Both forms 
Table 3 The Recapitulation of Respondent's Response Toward Associative Social Interaction of Children with Special Needs

\begin{tabular}{lccc}
\hline & $\begin{array}{l}\text { The Associative } \\
\text { Social Interaction } \\
\text { of Children with } \\
\text { Special }\end{array}$ & & \\
\hline Alternative Answers & Option Category & Frequency & Percentage \\
\hline Strongly Agree & 1 & 7 & $2,8 \%$ \\
Agree & 2 & 166 & $66,4 \%$ \\
Doubt & 3 & 73 & $29,2 \%$ \\
Disagree & 4 & 4 & $1,6 \%$ \\
Strongly Disagree & 5 & 0 & $0 \%$ \\
& Total & 250 & $100 \%$ \\
\hline
\end{tabular}

Source: The researcher data calculation result, 2019

are indicators of social interaction at the same time. Both indicators can be seen directly by the respondent's progress, the students' parents. Social interaction is realized in 9 statements, with five items distribution of associative form indicators and four items dissociative form indicators. The first associative social process indicator is cooperation. When play therapy activities take place, children work together to play games in groups to get a common goal, that is victory. In addition, the cooperative attitude of children to follow the rules of the game can also be categorized in the development of children's cooperation. The second associative social process indicator is agreement or commitment. In this sense, the agreement is not a formal agreement involving the law but practiced through simple promises in everyday life. The development of child's ability to carry out the commitment, that is when the child remembers his promise, for example, the promise to throw garbage in its right place and so on. The last indicator of the associative social process is negotiation, and it is an adjustment activity between the wishes and obligations of children given by the teacher. The teacher must be able to find out a proportional treatment between his wishes and children's wishes. The negotiation ability of children with special needs includes the ability to express their opinions and desires, then adjust and control those desires to be in line with the obligations they receive. Here are the results of questionnaire recapitulation from several dimensions on the Y (Associative) variable, as follows.

Table 3 explains that 50 respondents have a tendency to choose to agree to alternative answers, which is $66.4 \%$ with a frequency of 166 choices. The tendency of next respondent's answers settled down in answer choice of doubt or $29.2 \%$ with a frequency of 73 choices, followed by an alternative answer of strongly agree at $2.8 \%$, which has seven choices frequency, and an alternative answer of disagreeing gained 1.6\%, with frequency four options. Furthermore, the indicator of the first dissociative social process is a competition which is a willingness to win that is implemented by students in various activities when playing games in play therapy. This capability must be possessed by children so that children remain enthusiastic and do their best in every activity. The second indicator of dissociative social process is resistance that is expressed by students in various ways of expressions, attitudes, and actions. Teachers must be able to direct and guide students to make them interested in playing. However, this resistance is not always negative; there are times when this student's resistance is positive. Just like when there are actions of friends or other people in play therapy that are out of the norm or hurt him, he will fight back either with actions or words. The last indicator of dissociative social process is contravention which is a difference that appears from children's side with things or situations around them. On the one hand, the 
Table 4 The Recapitulation of Respondent's Response Toward Dissociative Social Interaction of Children with Special Needs

\begin{tabular}{lccc}
\hline & $\begin{array}{l}\text { The } \\
\text { Social Interaction of } \\
\text { Children with Special } \\
\text { Needs }\end{array}$ & & \\
\hline Alternative Answers & Option Category & Frequency & Percentage \\
\hline Strongly Agree & 1 & 7 & $3,5 \%$ \\
Agree & 2 & 88 & $44 \%$ \\
Doubt & 3 & 75 & $37,5 \%$ \\
Disagree & 4 & 29 & $14,5 \%$ \\
Strongly Disagree & 5 & 1 & $0,5 \%$ \\
& Total & 200 & $100 \%$ \\
\hline
\end{tabular}

Source: The researcher data calculation result, 2019

teacher must be able to direct the differences in order to make students remain on track, but on the other hand, the teacher must also respect the differences of children. This contradiction can be seen in the way children express their differences.

Table 4 explains that of the 50 respondents who filled out four questions about the dissociative process of children with special needs, the majority of respondents chose the alternative answer 'agree,' that is $44 \%$, with 88 frequency choices, choice 'doubt' is $37.5 \%$ with a total 75 choices frequency in total, choice 'disagree' by $14.5 \%$ with a frequency of 29 choices, 3.5\% strongly agree with a frequency of 7 choices, and strongly disagree $0.5 \%$ with a frequency of 1 choice. Based on the results of the variable recapitulation, here are the results of the validity test on the $\mathrm{X}$ variable.

Based on table 5, all statements used as a data collection tool regarding the $\mathrm{X}$ variable (Therapeutic Communication) with 11 statements had $t$ count value $>$ the specified $t$ table value, then it indicates a positive correlation value. Thus, the statement in the questionnaire is valid and proper to be a tool for collecting the research data.

Based on table 6 , all statements used as a data collection tool regarding the $\mathrm{Y}$ variable (Social Interaction) with nine statements had atcount value bigger than the specified t- ${ }_{\text {table }}$ value, thus indicating a positive correlation value. Therefore, the statement in the questionnaire is valid and feasible to be used as a tool to collect data in this study. The analysis that has been described shows that the implementation of play therapy makes a good contribution so that it has a healing impact on children; this play therapy can increase feelings of joy, happiness, and sensitivity in interaction so that parents can more easily be able to conduct personal relationships. Therapeutic communication in play therapy is influenced by several factors, such as family educational background, incomplete facilities and infrastructure, and lack of parental understanding collaboration meaning that should be built comprehensively. This is in accordance with the research result on Play Therapy as Therapeutic Communication for Nurses in Toddlers, which explained that therapeutic communication is used to play therapy as a means of communication to avoid boredom, indecision, and stress on children. The therapeutic communication carried out by nurses is through a process of introduction or approach aiming at getting to know each other better. The introduction process is done by getting to know the condition or condition of the patient's family background and the patient himself. This is executed to make nurses easier to apply to play therapy in the therapeutic communication process. The patient's response that the nurse received from a toddler was crying and screaming (Kamaratih, 2013). It is also proven that Child-Centered Play therapy shows a positive improvement in children's social and emotional development. This therapy 
Table 5 The X Variable of Validity Test Result (Therapeutic Communication)

\begin{tabular}{ccccc}
\hline No Item & $\begin{array}{c}\text { P e a r s o } \\
\text { Corelation }(\mathrm{r})\end{array}$ & Tcount & Ttable & Explanation \\
\hline Statement 1 & 0,570 & 4,810 & 2,009 & Valid \\
Statement 2 & 0,211 & 2,298 & 2,009 & Valid \\
Statement 3 & 0,587 & 5,022 & 2,009 & Valid \\
Statement 4 & 0,477 & 3,763 & 2,009 & Valid \\
Statement 5 & 0,559 & 4,667 & 2,009 & Valid \\
Statement 6 & 0,503 & 4,037 & 2,009 & Valid \\
Statement 7 & 0,426 & 3,266 & 2,009 & Valid \\
Statement 8 & 0,503 & 4,037 & 2,009 & Valid \\
Statement 9 & 0,479 & 3,785 & 2,009 & Valid \\
Statement 10 & 0,467 & 3,659 & 2,009 & Valid \\
Statement 11 & 0,433 & 3,328 & 2,009 & Valid \\
\hline
\end{tabular}

Source: The researcher data calculation result, 2019

is an effective therapy to apply for children with autism (Salter, 2016).

This study also showed that the reliability of the instrument on $\mathrm{X}$ variable (questionnaire) used in this study was to obtain the desired information that can be relied on a data collection tool and able to reveal real information. A questionnaire can be said to be reliable if one's answer to a statement is continuously consistent over time. Based on the results obtained, the value is 6.861 , and $t_{\text {he table }}$ is 2.011 . The test results of these instruments indicate that all instruments have a value ${ }_{\text {count }}>{ }_{\text {table }}$, so the measuring instrument of a questionnaire in this study can be declared reliable and suitable for research. At the same time, the instrument reliability on the Y variable (questionnaire) was obtained based on the results of the ${ }_{\text {count }}$ value 4.718 and $t_{\text {able }}$ 2.011. The test results of these instruments indicate that all instruments have a value of ${ }_{\text {count }}>_{\text {table }}$, so the measuring instrument of a questionnaire in this study can be declared reliable and suitable for research.

Empathy is one indicator of therapeutic communication taking place in play therapy. Therefore, it is necessary to measure the effect of therapy on students' social associative process, which is one of the social interaction indicators. Based on the data presented, the correlation coefficient value of empathy influence on associative social process showed a value or score of 0.443 . The significance value of the empathy effect on students' associative process showed the value of 0.000 . In accordance with the provision that has been set, if the significance value is less than 0.05 , it can be stated that the two variables tested have a significant effect. At the same time, the simple regression test of empathy for the dissociative social process was carried out to measure the effect of therapy on students' dissociative social process, which became one of the indicators of social interaction. Based on the data shown in Table 4.40, the correlation coefficient value of the empathy influence on dissociative social process showed value or score 0.544. Based on table 4.7 (Score Interpretation Table) then the value is in the interval $0.40-0.70$, meaning that it is in the fairly strong category. That is, empathy in play therapy has a strong enough influence on the dissociative social process of students at SLBC YKB Garut. The significance value of the effect of empathy on students' associative process showed a value of 0.004 . In accordance with the provisions that have been set, if the significance value is less than 0.05 , it can be stated that the two variables tested have a significant effect.

While the correlation coefficient value of the influence of warmth on associative social process showed a value or score of 0.850 , according to the table of correlation coefficients, the value is in the interval $0.70-0.90$, which means it is in a strong category. This means that 
Table 6 The Y Variable of Validity Test Result (Social Interaction)

\begin{tabular}{ccccc}
\hline No Item & $\begin{array}{c}\text { P } \text { e a r s o } \mathrm{n} \\
\text { Corelation }(\mathrm{r})\end{array}$ & T Count & T Table & Explanation \\
\hline Statement 1 & 0,204 & 2,445 & 2,009 & Valid \\
Statement 2 & 0,469 & 3,680 & 2,009 & Valid \\
Statement 3 & 0,484 & 3,837 & 2,009 & Valid \\
Statement 4 & 0,331 & 2,427 & 2,009 & Valid \\
Statement 5 & 0,209 & 2,479 & 2,009 & Valid \\
Statement 6 & 0,621 & 5,489 & 2,009 & Valid \\
Statement 7 & 0,652 & 5,956 & 2,009 & Valid \\
Statement 8 & 0,686 & 6,524 & 2,009 & Valid \\
Statement 9 & 0,497 & 3,397 & 2,009 & Valid \\
\hline
\end{tabular}

Source: The researcher data calculation result, 2019

warmth in play therapy has a strong influence on the associative social process of students at SLBC YKB Garut. The significance value of the empathy effect on students' associative process showed value 0.000 . As provisions have been set, if the significance value is less than 0.05 , it can be stated that the two variables tested have a significant effect. Based on the data presented, the correlation coefficient value of the influence of warmth on dissociative social process showed a value or score of 0.880 . This means that warmth in play therapy has a strong influence on the dissociative social process of SLBC YKB Garut students. The significance value of the empathy effect on students' associative process showed value 0.001 . Based on the rules that have been set, if the significance value is less than 0.05 , it can be stated that the two variables tested have a significant effect.

Meanwhile, the regression value as a symbol of the coefficient showed value 0.428 , which is the correlation of the two variables value. This value can be interpreted as a relationship between the two variables lying in the sufficient category. The table above also obtained the value of R Square or Coefficient of Determination (KD) which showed how good the regression model formed by the interaction of independent and dependent variables is. The $\mathrm{KD}$ value obtained is 0.283 . Therefore, it can be interpreted that the $\mathrm{X}$ variable has a contribution effect of $28.3 \%$ on the $\mathrm{Y}$ variable.

As reinforcement of the analysis on this discussion, the researcher explained that SLBC
YKB Garut performed various types of games in play therapy, this is conducted to make children happy with the games they are playing. Different games and procedures will create a different goals. There are types of games aiming at children's motor skills, training children to speak and compose sentences, training children's response speed, maintaining children's physical fitness, channeling children's hobbies and artistic talents, and so on. In this study, the researcher observed several types of games that were often used, such as play therapy for throwing, catching, and balls, playing color blocks and ball therapy, role-playing therapy, nature tourism play therapy, and vocational play therapy (child independence). Some types of games carried out are related to changes in behavior, as the research results from the journal of communication for students with special needs show that communication messages exchanged in the classroom in learning and teaching activities are executed in two forms, they are verbal and nonverbal forms. For children with special needs, nonverbal language is more dominant than verbal language. The verbal message is carried out through spoken and written forms, while the nonverbal message is executed through hand movements, gestures, and facial expressions (Nurjaman, 2018). Some therapies performed are shown in figures 1 and 2 .

Play therapy through catching and throwing the ball is executed on physical education subject on Fridays as warming up activity after 


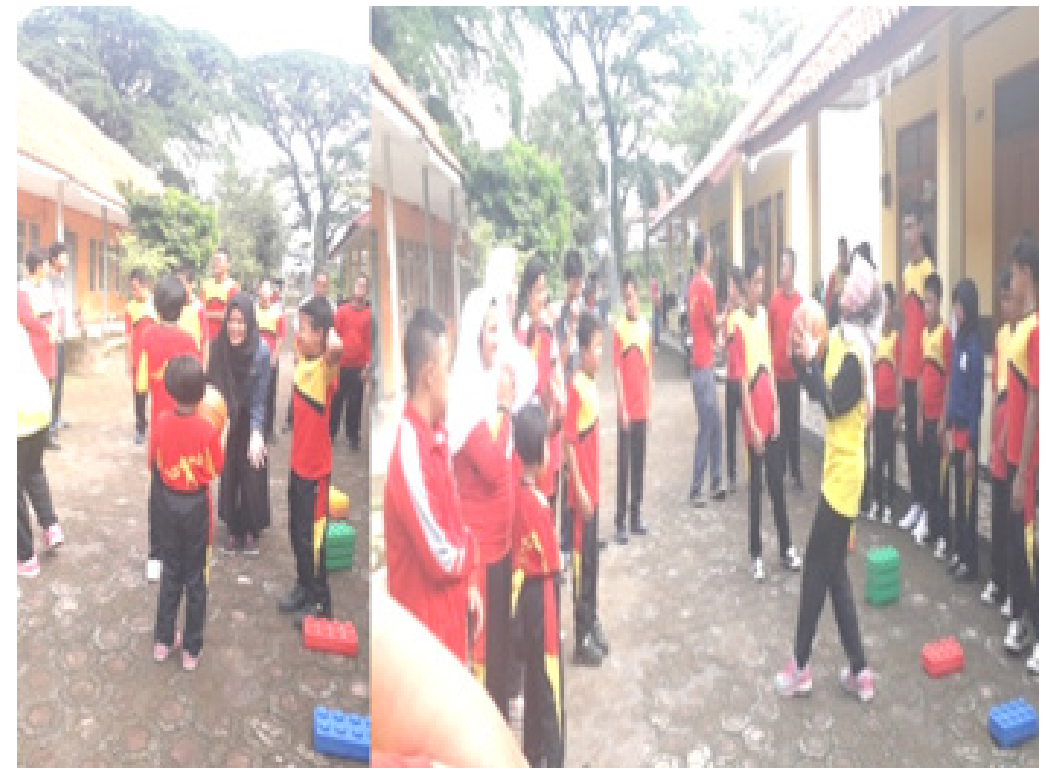

Source: Research results, 2019

Figure 1 Play Therapy Catching and Throwing Balls Play

jogging. This therapy aims to train the child's response to be responsive and not afraid of the ball. Through this therapy, we can also determine the child's ability to predict distance and control his strength. In this play therapy activity, some children have been able to adjust the distance between themselves and the therapist and control their strength in throwing the ball so that it shot on target. However, there were also children who avoided (did not want to catch the ball) because they were afraid of getting hurt if the ball hit part of the body. The procedure for this game is the same as throwing and catching a ball in general. Students form a large circle, while the therapist stands in the middle as the center. Some children who have

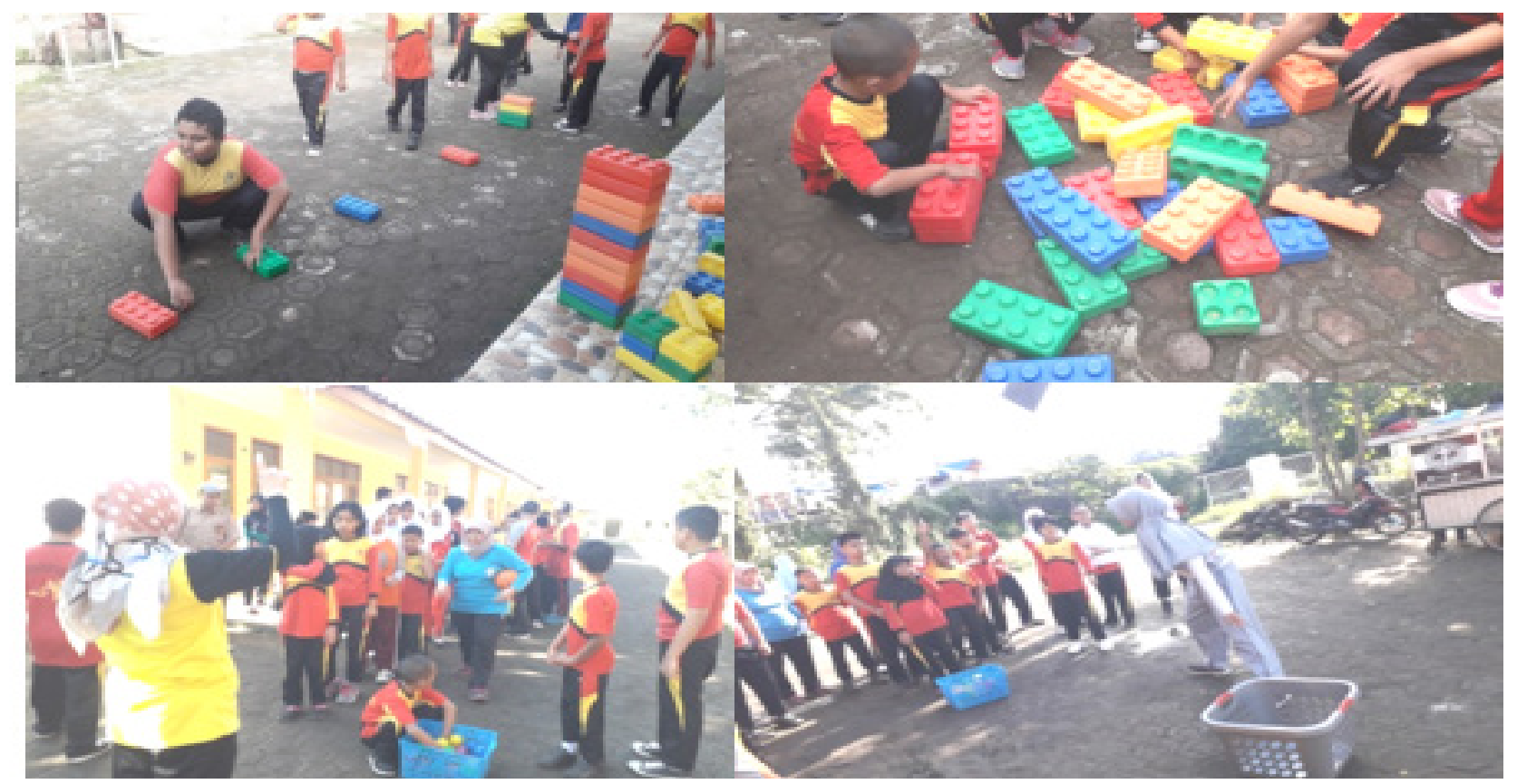

Source: Research results, 2019

\section{Figure 2 Play Therapy of Colour Ball and Square}

The effect of play therapy as a therapeutic communication on social interactions of children with special needs (Zikri Fachrul Nurhadi, Rosanti Utami Dewi, Syaidah Nurhalimah) 
physical weakness or are difficult to manage are usually accompanied directly by a therapist assistant. Then the therapist starts throwing the ball at the student, and the student must catch the ball, then throw it back at the therapist. The activity of throwing and catching the ball is carried out in turns till all students get their turn.

\section{CONCLUSION}

Empathy manifested in understanding, sensitivity, knowledge, and direct action from the teacher in play therapy has a significant influence on the social interaction of the Children with Special Needs associative process, which is implemented through cooperation, agreement, negotiation, as proven by a significance value 0.000 , and score 0.443 which indicates a quite strong influence of empathy on social interaction process associative Children with Special Needs at SLBC YKB Garut.

Empathy manifested in understanding, sensitivity, knowledge, and direct action from the teacher in play therapy has a significant influence on social interactions in the dissociative process of children with special needs, which is manifested in the form of competition, resistance, and contravention. This is proven by a significance value of 0.004 and a score of 0.554 , which shows a fairly strong influence of empathy on the social interaction of the dissociative process of children with special needs at SLBC YKB Garut.

The warmth that is manifested in eye contact, touch, listening activities, and the teacher's voice intonation in play therapy has a significant influence on the social interaction of the children with special needs associative process, which is manifested in the form of cooperation, agreement, and negotiation. This is proven by a significant number of 0.000 and a score of 0.850 , which shows the strong influence of empathy on the social interaction of the associative process of children with special needs at SLBC YKB Garut.

The warmth that is manifested in eye contact, touch, listening activities, and the teacher's voice intonation in play therapy has a significant influence on social interactions with special needs children's dissociative processes, which are manifested in the form of competition, resistance, and contravention, as proven by a significance value 0.001 , and a score 0.880 which means that shows the strong influence of empathy on social interactions of the dissociative process of children with special needs at SLBC YKB Garut. In general, the effect of play therapy as therapeutic communication on the social interactions of children with special needs is shown by the correlation coefficient 0.428 , which can be interpreted that the relationship between the two research variables is in a fairly strong category.

\section{REFERENCES}

Arwani. (2012). Communication in nursing Jakarta: Medicine EGC.

Atmaja, J. R. (2018). Education and guidance for children with special needs. bandung: pt. remaja rosdakarya.

Effendy, O. U. (2013). Theory and practice of communication science. Bandung: Remaja Rosdakarya.

Hatiningsih, Nuligar. (2013). Play therapy for improving concentration on child with attention deficit hyperactive disorder (ADHD). Universitas Muhammadiyah Malang. Journal of Applied Psychology 1(2). DOI: https://doi.org/10.22219/jipt. v1i2.1586.

Hergenhahn B.R, O. M. (2015). Theories of learning (learning theory). Jakarta: Kencana Prenada Media Group.

Iswari, M. (2007). The life skills for children with special needs. Jakarta: National Education Department.

Indriyani, L. (2011). Play therapy: landslide mitigation learning for untuk children with special needs. Vulcanology dan Geological Order Bulletin page. 7-15.

Kamaratih, Clarisa. (2013). Play Therapy as nurse therapeutic communication on three-year-old baby. Paper. Faculty of Communication Science Universitas Padjajaran: Bandung.

Komariah, Kokom, et al. (2013). Health communication pattern in serving and providing information toward tb at local health centre in Bogor. Faculty of Communication Science, Universitas Padjadjaran: Bandung. Communication Research Journal, 1(2). DOI: 10.24198/jkk. 
v1i2.6042.

Luddin, A. M. (2010). The principles of counselling: view of theory and practice. bandung: citapustaka media perintis.

Nida, F. L. (2013). The communication of children with special needs. AT-TABSYIR, Journal of Communication for Islamic Broadcast, 1(2), 163-189. DOI:10.21043/ at-tabsyir.v1i2.431.

Nurjaman, E. Y. (2018). The communication of students with special needs in classroom. Journal of Politics and Communication Science, 8(2), 12-24. DOI:DOI: https://doi. org/10.34010/jipsi.v8i2.

Government regulation of republic of Indonesia number 72/ 1991 About Special Education

Rahmawati, Suryati. (2016). The influence of play therapy towards social interaction of autistic child at sldb Prof. Dr. Sri Soedewi Masjchun Sofwan, SH Jambi in 2014. Jurnal Ilmiah. Universitas Batanghari Jambi, 16(1), 142-147. DOI $\underline{10.33087 /}$ jiubj.v16i1.94.

Ray, C. D., Bratton, S., Rhine, T., \& Jones, L. (2001). The effectiveness of play therapy: Responding to the critics. International Journal of Play therapy, 10, (1), 85-108. DOI: $10.1037 / \mathrm{h} 0089444$.
Salter, Kerri, et al. (2016). The effects of childcenter play therapy (ccpt) on the social and emotional growth of young Australian children with autism. International Journal of Play Therapy, 25(2), 78-90. https:// dx.doi.org/10.1037/pla0000012.

Soekanto, S. (2013). Introuduction to sociology. Jakarta: Rajawali Pers.

Somantri, D. T. (2014). Special children phsycology. Bandung: Refika Aditama.

Sugiyono, P. D. (2015). The educational method of research quantitative and qualitative and $r \& d)$. Bandung: Alfabeta.

Suryani. (2016). Theory and practice of therapeutic communication Jakarta: Medicine and Health EGC.

Wardani, I. d. (2014). An introduction to special needs children. Jakarta: Universitas Terbuka.

Windyaningrum, Rachmawati. (2014). Therapeutic communication of addiction counsellor towards drugs abuse victim at palma house.Therapeutic Community Kabupaten Bandung Barat. Faculty of Communication Science, Universitas Padjadjaran: Bandung. The Journal of Communication Research (JKK), 1(2). DOI: $10.24198 / \mathrm{jkk} . v 2 \mathrm{i} 2.7384$. 